\title{
Effects of slip on eccentrically loaded multiple-ply girder timber trusses
}

$1 \quad$ Walter M. G. Burdzik PrEng, MEng, PhD Professor, Department of Civil Engineering, University of Pretoria, Pretoria, South Africa

2 Sarah A. Skorpen PrEng, BEng Department of Civil Engineering, University of Pretoria, Pretoria, South Africa
3. Karin Jansen van Rensburg BEng

Department of Civil Engineering, University of Pretoria, Pretoria, South Africa
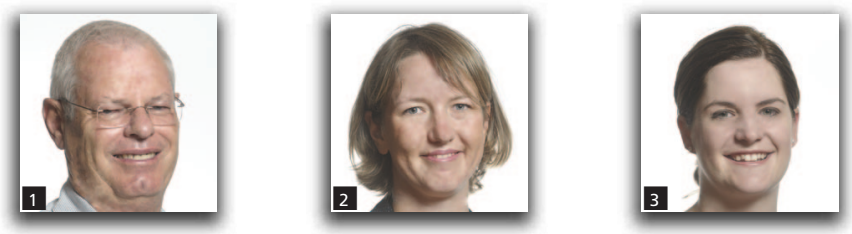

Recent roof failures in South Africa, of multiple ply nail plated trusses, have necessitated a rethink about the way in which timber trusses are analysed. The authors believe that the relative slip between plies caused by a torsional moment as a result of eccentric loading is a possible reason for some of the failures. The design assumption in South Africa and America is that all the plies share the applied load equally; Eurocode 5 (BS EN 1995-1-1:2004) does not cover the design of multiple ply trusses; and BS 5268-3:2006 recommends additional load factors to be applied to eccentrically loaded truss components with the outer ply being loaded more than the inner plies, as a result of the torsion induced by an out-of-plane eccentricity. In this paper, a matrix stiffness method is used to show that, by ignoring the eccentric loading and relative slip between the trusses, the member and plate force may be underestimated by a factor in excess of two for a three ply girder truss. A single three-ply girder truss test is used to illustrate the merits of the method. The required load factors calculated also show that the magnification factors in BS 5268-3:2006 are lower than they should be.

\section{Notation \\ $d$ diameter of the fastener in $\mathrm{mm}$ \\ $k \quad$ nail stiffness in $\mathrm{N} / \mathrm{mm}$ or $\mathrm{kN} / \mathrm{m}$ \\ $F_{\mathrm{L}}$ design load \\ $F_{\mathrm{R}} \quad$ resistance force: that is, failure load \\ $\rho_{\mathrm{m}} \quad$ density of the timber in $\mathrm{kg} / \mathrm{m}^{3}$}

\section{Introduction}

The matrix-stiffness method of analysis has made it very easy for timber truss designers to analyse the many trusses that go into making up the roof of a building. The layout can be drawn with great efficiency, giving the designer all possible truss layouts very quickly. This aspect of the design requires some technical expertise from the designers as they need to know whether a layout is suitable or not. Once they have decided on a layout, the truss configuration is generated with very little further input. Not only does the software analyse each truss and choose the optimum configuration, size and grade of member, it also draws up the cutting bill, manufacturing sheet and calculates the connector plate size. All sizes are then checked to see whether they meet the requirements of SANS 10163: Part 1 (SANS, 2003a) or SANS 10163: Part 2 (SANS, 2001). Load paths are also calculated, so that every truss may be allocated the correct load. This then makes it possible for the designer to obtain the cheapest solution and, hopefully, also the most structurally efficient.

In this whole process, the software developer may be aware of the limitations of the program, but the general user of the software has no idea as to whether the design has satisfied all the basic principles of structural analysis as well as all the requirements of the timber design code of practice SANS 10163: Part 1 or Part 2. The whole design process has now been relegated to use of a 'black box'.

A two-dimensional linear elastic analysis of single in-plane loaded trusses may be correct, but the authors have their reservations about this approach for the analysis of multiple-ply girder trusses. Neither SANS 10163: Part 1 nor Part 2, have any guidelines with respect to the design of multiple-ply girder trusses and this omission is then used by the designers to ignore 


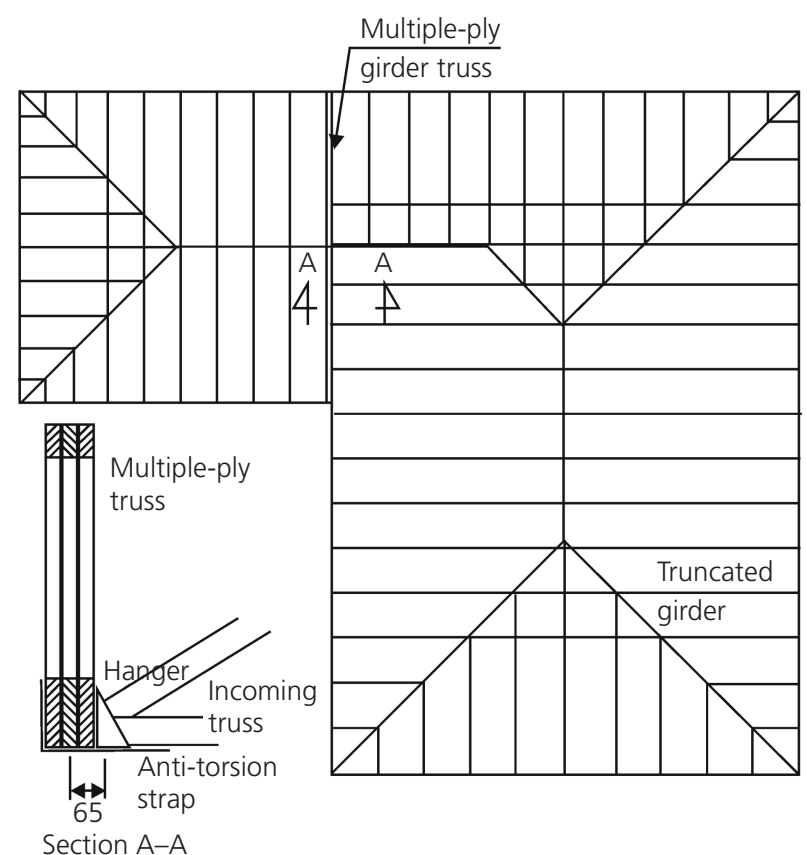

Figure 1. Roof layout showing possible multiple-ply girder truss and current fixing (dimensions in $\mathrm{mm}$ )

the possibility of increased forces in the outside plies of girder trusses loaded on one face. Figure 1 shows a plan and section of a possible positioning or use of a multiple-ply girder truss.

The current analysis of the multiple ply trusses (MPT) assumes that all loads are in-plane and act on the centreline of the combined individual girder trusses so that there is no eccentricity of the loads. Two types of truss hangers are used to connect incoming trusses to the multiple ply truss. For lighter loads the hanger is nailed or bolted to the bottom chord and for heavier loads the truss hanger may have a strap that is bolted to vertical webs (see Figure 2).

The fact that in a three-ply girder truss the load may be $65 \mathrm{~mm}$ away from the assumed loading plane is ignored. Straps, called anti-torsion straps, are used to tie the incoming trusses to the girder truss. Prior to the introduction of strapping, the bottom chord of some girder trusses rotated and deflected so that the

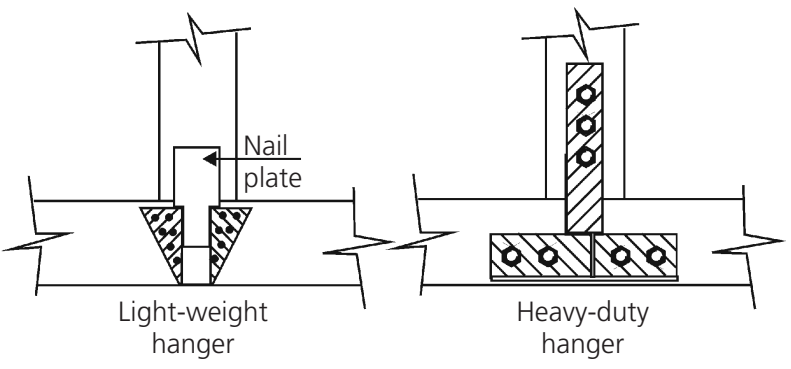

Figure 2. Light-weight hanger and heavy-duty hanger incoming trusses literally fell off their support hangers. The common belief in the industry is that the anti-torsion straps minimise, if not totally negate, the torsion being applied to the bottom chord. This assumption, however, is only correct if the incoming trusses butt up tightly against the girder truss and relative rotation of the bottom chord is prevented.

The authors have identified eccentric loading, namely loading on the face of the outer ply, and the relative slip between the trusses as possible causes for concern. They believe that a combination of cumulative design assumption errors may increase the probability of failure to an unacceptable level. In this paper a single nail layout will be used as a method of illustrating the benefits of a matrix stiffness analysis to quantify the increase in forces as a result of eccentric loading and slip. It should be remembered that the nails and bolts can only transfer loads between the trusses once slip has occurred. The friction between the trusses must be ignored, as long-term expansion and contraction of the timber, as a result of moisture content changes, will negate any friction that may originally have been present. A typical multiple ply girder truss failure is shown in Figure 3.

It is of interest to note that during the testing of the three-ply girder trusses without torsional restraint at the hangers, Enjily and Whale (1994) found that the ratio between failure load and design load, the so-called safety factor, varied between a low of 1.09 and a high of 1.75 with a mean of 1.45 and a coefficient of variation of $19 \%$. Figure 4 assumes a normal distribution for both the loading and the strength. The safety factor, SF, is defined by the distance between the mean of the load effect and the mean of the failure strength. The probability of the load exceeding the strength is in the portion where the two distributions overlap. Dr Martin Slavic set up the graphs during a legal dispute about safety factors and the probability of failure for a structure that was under-strength according to the concrete code. For every

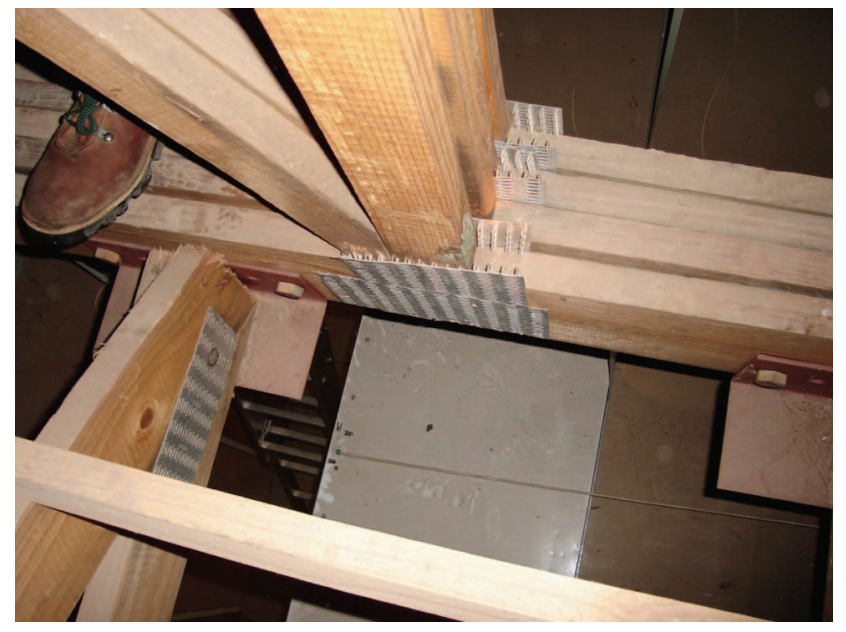

Figure 3. This shows the outer ply loading of a multiple ply girder truss and tensile failure (nail plate pulling out) 


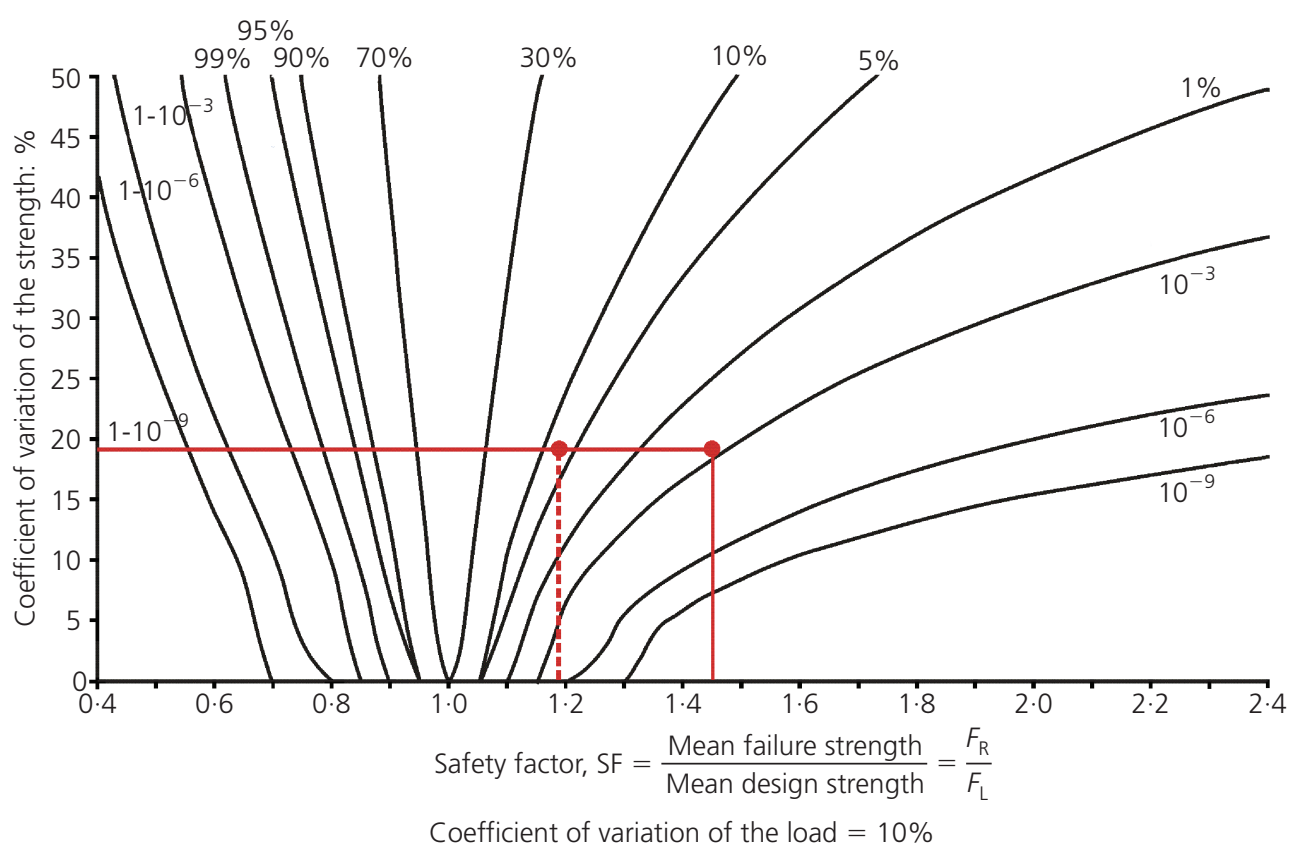

Figure 4. Probability of failure graph for various characteristic error of resistance based on normal distributions. Graph prepared by Martin Slavic

coefficient of variation of the load a whole new set of graphs are obtained. A $10 \%$ coefficient of variation on the load seemed, to the authors, to be an acceptable value. These graphs can be used to illustrate that a structure, which according to a code is understrength, may still statistically have an acceptable probability of failure. The three-ply trusses, without torsional restraint, tested by Enjily and Whale (1994) are used to illustrate how the graphs may be used. Taking the mean safety factor of 1.448 and the coefficient of variation of $19 \%$ into account, the probability of load exceeding strength will be slightly more than 1 in 1000 (marked with a red line).

$F_{\mathrm{R}}=$ resistance force: that is, failure load.

$F_{\mathrm{L}}=$ design load.

If one now takes the long-term loss in strength of the timber into account, the probability of failure of these girder trusses increases significantly. SANS 10163: Part 2, has a modification factor for duration of load that is supposed to reflect the loss in strength with time. The relevant factor for a split of 50\% permanent and $50 \%$ short term imposed load would be $1 \cdot 22$. To change the short duration strength to long duration strength, the strength must be multiplied by the inverse of $1 \cdot 22$ : that is, $0 \cdot 82$. This would then change the mean safety factor achieved by the three-ply trusses tested by Enjily and Whale (1994) to $1 \cdot 186$ and the coefficient of variation would still be $19 \%$. The probability of failure would then increase to about 7\% (marked with a dashed red line). An acceptable probability of load effect exceeding strength of critical elements is 1 in $10^{6}$. Taking the long duration loss of strength into account it is clear that designing multiple ply girder trusses without taking cognizance of the slip between the plies of the girder leads to an unsafe structure.

Enjily and Whale (1994) undertook a large number of full-scale tests on three- and four-ply girder trusses and, thereafter, extrapolated using computer analyses to include two and five ply girder trusses. Their recommendations are included in BS 5268-3:1998 (BSI, 1998) which gives additional load factors to be applied to nail plates and web members of multiple-ply girder trusses. They proposed a force modification factor for eccentrically loaded components that depends on the degree of torsional restraint provided by the bracket or hanger. Enjily and Whale (1994) found that the maximum torsional moment restraint, $T_{\mathrm{r}}$, that could be equilibrated by the brackets or strapping was found to be $40 \%$ of the torsional moment applied by the eccentric loading. The remaining $60 \%$ of the moment had to be carried by the girder truss in torsion. Table 1 is an extract from Enjily and Whale (1994) and only the values for up to four-ply trusses are given.

In the recommendations of their paper, Enjily and Whale (1994) went further and proposed that, among others, the following two topics required investigation:

'Investigation should be continued as to what portion of the eccentric load is resisted by the individual plies of girders.

'The distribution of torsion, tension, shear and bending stresses at the bottom chord nodes of girders.' 


\begin{tabular}{cccccc}
\cline { 2 - 4 } & $T_{\mathrm{r}}=0$ & $T_{\mathrm{r}}=0.1$ & $T_{\mathrm{r}}=0.2$ & $T_{\mathrm{r}}=0.3$ & $T_{\mathrm{r}}=0.4$ \\
\hline 1 & 1.0 & 1.0 & 1.0 & 1.0 & 1.0 \\
2 & 1.33 & 1.13 & 1.13 & 1.13 & 1.13 \\
3 & 2.00 & 1.70 & 1.40 & 1.40 & 1.40 \\
4 & 3.00 & 2.60 & 2.20 & 1.80 & 1.80
\end{tabular}

Table 1. Proposed force magnification factors for eccentrically loaded truss components

Burdzik (2005) in his paper attempted to replicate the values that were obtained by Enjily and Whale (1994) and to obtain the forces and bending moments in the bottom chord as suggested in their paper. In his two dimensional analyses the trusses were stacked one above the other and connected by cables that had the same stiffness as the nailed and bolted connections. Although Burdzik (2005) was able to obtain the similar values for the three- and four-ply girder trusses without taking the torsional moments into account, a theoretical approach of adding the torsional moment lead to far bigger values than those found by Enjily and Whale (1994). In this paper the authors use a three-dimensional approach to solving the forces and moments in the individual trusses.

The Truss Plate Institute of America Draft Standard, BSR/TPI 1-2002 (Truss Plate Institute, 2002), has the following clauses covering the design of multiple ply girder trusses:

7.4.2.3 If a structural member imposing a load on a girder is continuous across all plies, the load shall be considered to be equally distributed to all plies.

7.4.2.4 The maximum number of plies shall be five, if the structural members imposing a load are attached to one side of the girder, or six, if the structural members imposing a load are attached to both sides of the girder.

7.4.5.1 Girders with up to three plies shall be connected by nailing, bolting, or other approved fasteners in accordance with an approved design criteria. Girders with four or more plies, and having structural members imposing a load on one side of the girder, shall be connected by bolting, a combination of nailing and bolting, or by other approved fasteners.

Either nails, bolts, or other approved fasteners shall be designed to transmit 100 percent of the imposed load from one side; the values for more than one type of approved fastener in the same connection shall not be combined. Webs in girders of any number of plies shall be permitted to be joined with nails.

7.4.5.2 Connections shall be designed to transmit load from ply to ply in accordance with the ply-to-ply load distribution assumed in the design of the girder. Connections shall be adequate to carry the cumulative load of the remaining plies.
In the TPI document no mention is made of the torsional moment that may be applied by the incoming trusses, nor is advice given on the possible slip between the plies of the multiple ply girder truss.

Eurocode 5 (BS EN 1995-1-1:2004, BSI, 2008) does not specifically cover the design of multiple ply girder trusses.

\section{Effect of nailing}

\subsection{Torsional rigidity of web and chord members}

In the South African multiple-ply girder truss industry trusses are nailed together with either $100 \mathrm{~mm}$ or $76 \mathrm{~mm}$ long drawn wire nails. Once the assembly is completed, the trusses are then bolted together at or near the nail plated joints. In the top and bottom chords, nails are placed $25 \mathrm{~mm}$ in from the edge of the timber and at a staggered pitch of $150 \mathrm{~mm}$. The web members are usually only nailed at a spacing of $300 \mathrm{~mm}$ along their centrelines (see Figure 5). As no information was available to give guidance with respect to calculating the torsional rigidity of members combined in accordance with SANS 10243 (SANS, 2013), a series of tests was undertaken by Burdzik and NKwera (2003) to establish the torsional rigidity of boards nailed together with $75 \mathrm{~mm}$ nails at the spacing suggested in SANS 10243 (SANS, 2013).

The results of the investigation were reported in Burdzik and NKwera (2003) and he found that there was no measurable
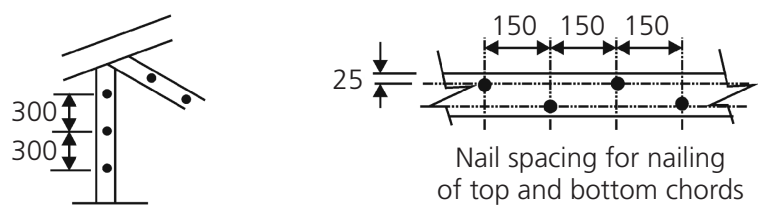

Nail spacing for nailing of top and bottom chords

Nail spacing for nailing

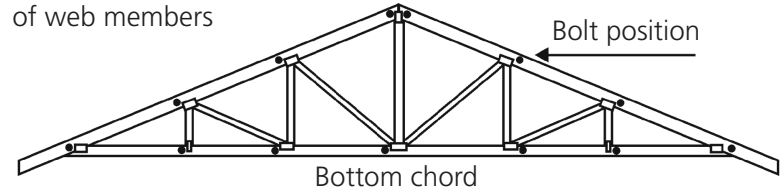

Positioning of bolts for multiple-ply girder trusses

Figure 5. Spacing of the nails and bolts used to construct the multiple-ply truss (dimensions in $\mathrm{mm}$ ) 
increase in the torsional stiffness, and the two members behaved as if they were not connected. The torsional stiffness was found to be the sum of the individual torsional stiffnesses. It is, therefore, possible in a multiple ply girder truss analysis to divide the torsional moment equally among the individual bottom chords.

\subsection{Stiffness of nails used in the fixing of plies}

The stiffness of the nailed and bolted connections was calculated using the equations given in the final draft of Eurocode 5 (BS EN 1995-1-1:2004 (BSI, 2008). Bosch (2005) found an average stiffness for $75 \mathrm{~mm}$ nails of $1350 \mathrm{kN} / \mathrm{m}$ in South African pine, SA pine, the stiffness being somewhat higher than that which the Eurocode equations would lead one to believe. The Eurocode may be conservative for nails in SA pine for short duration loading but should be applicable to long-term loading when a creep factor of 1.5 is applied. SA pine is a generic name that has been given to all species of pine grown in Southern Africa as no distinction is made once the timber has passed through the sawmilling process. The Eurocode 5 (BS EN 1995-1-1:2004 (BSI, 2008)) equation for the stiffness of nailed connections without pre-drilling is given by

1. $k_{\mathrm{ser}}=\rho_{\mathrm{m}}^{1 \cdot 5} \cdot d^{0 \cdot 8} / 30$

where $\rho_{\mathrm{m}}$ density of the timber in $\mathrm{kg} / \mathrm{m}^{3}, d$ diameter of the fastener in $\mathrm{mm}$ and $k_{\text {ser }}$ nail stiffness in $\mathrm{N} / \mathrm{mm}$ or $\mathrm{kN} / \mathrm{m}$

This equation is unfortunately not dimensionally independent and the correct dimensions must be applied to the parameters.

For connectors where pre-drilling is required the stiffness is given by

\section{2. $k_{\mathrm{ser}}=\rho_{\mathrm{m}}^{1 \cdot 5} \cdot d / 25$}

For nails that are hammered into the timber, without pre-drilling, Equation 1 may be used and the stiffness of a $3.5 \mathrm{~mm}$ diameter, $75 \mathrm{~mm}$ long nail is $867 \mathrm{kN} / \mathrm{m}$ and of a $4.0 \mathrm{~mm}, 100 \mathrm{~mm}$ long nail is $964 \mathrm{kN} / \mathrm{m}$ if the average density of timber is taken as $450 \mathrm{~kg}$ / $\mathrm{m}^{3}$. Tests done in the laboratory at the University of Pretoria have shown that this stiffness can easily be $50 \%$ higher for short duration loading where creep and shrinkage have not yet occurred. The stiffness that was assumed in the analyses, where $100 \mathrm{~mm}$ long, $4 \mathrm{~mm}$ diameter, nails were used, was taken to be $1446 \mathrm{kN} / \mathrm{m}$. T bolts have a much higher long duration loading stiffness of $4580 \mathrm{kN} / \mathrm{m}$, but will first have to slip anything between $0.5 \mathrm{~mm}$ and $1.0 \mathrm{~mm}$, owing to the oversized hole. At a slip of $1 \mathrm{~mm}$, the nails will be loaded past their working or permissible load. The slip that is required before the bolts transfer load can be taken into account in the analysis.

The authors realise that the timber has a significant variation in stiffness, not only between members but also in the length of the individual member. This has not been taken into account during the analysis and would require a separate Monte Carlo simulation investigation to ascertain whether the difference in the distribution of forces is significant. All members were thus assumed to have the average stiffness for the given grade of timber.

\subsection{Matrix stiffness analysis}

It is possible to analyse a multiple-ply truss three dimensionally by using solid or beam elements and simulating the nail plates at joints and the nails between the trusses with springs. The input of coordinates is fairly complex, as each nail or theoretical position of a nail will have to be defined. Coordinates can be so close together that it becomes difficult to define the solid elements. This analysis would have the advantage over physical testing of the multi-ply trusses as it would then answer the questions of how much each ply carries, as well as giving an indication of the bending moment distribution in the loaded bottom chords. However, this method does not take the distance between the planes of trusses into account.

An easier method is to have the trusses placed next to each other and to simulate the nail with a flexural member in double flexure, having the same stiffness as the nail. The stiffness of the nail is generally based on a nail that is in shear and goes into double flexure. The advantage of this method is that it is easy to track the node points of each individual truss. It also takes the distance between the planes of the trusses into account and allows for some of the torsion to be transferred between the trusses.

The size of the flexural member that connects the individual elements can be obtained from basic slope deflection equations (Coates et al., 1988). Nail stiffness is determined by testing of nails that go into double curvature, so it is possible to determine the flexural stiffness of a member in double curvature that has the same stiffness as the nail. See Figure 6 for the forces involved.

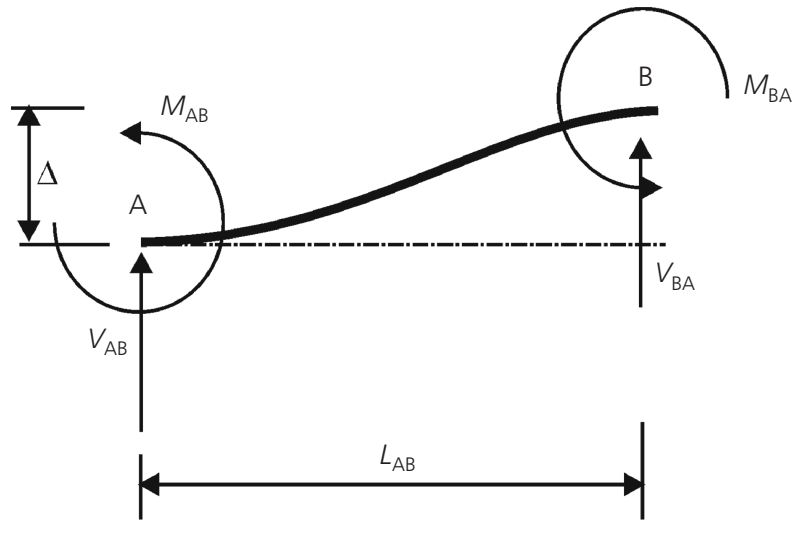

Figure 6. The forces that are assumed to be present in the nailed joint so that double flexure may be obtained 


$$
\begin{aligned}
V_{\mathrm{BA}} & =\frac{-M_{\mathrm{AB}}-M_{\mathrm{BA}}}{L_{\mathrm{AB}}} \\
& =\frac{6 E I_{\mathrm{AB}} \times \Delta+6 E I_{\mathrm{AB}} \times \Delta}{L_{\mathrm{AB}}^{3}}
\end{aligned}
$$$$
3 .
$$

But $V_{\mathrm{AB}} / \Delta$ is equal to the stiffness of the nail, $K_{\mathrm{ser}}$.

The required flexural stiffness $E I$ can be calculated as follows

4. $E I_{\mathrm{AB}}=\frac{k_{\mathrm{ser}} \times L_{\mathrm{AB}}^{3}}{12}$

\section{Analytical and experimental investigation}

A typical three-ply truss was analysed using the matrix stiffness method described, and then constructed and tested in the laboratory at the Department of Civil Engineering at the University of Pretoria. The test procedure and results are detailed in the following section.

\subsection{Multiple-ply truss experimental set-up}

The experimental set-up was undertaken by De Koning (2005) in the Department of Civil Engineering at the University of Pretoria. This work aimed to quantify the distribution of the axial forces in one of the web members, so that this could be compared with the analytical solution.

Owing to laboratory and financial constraints, the span was restricted to a $6 \mathrm{~m}$ span, three-ply King post truss with a pitch of $26^{\circ}$. For the design of the trusses, seven incoming trusses were assumed spaced at $760 \mathrm{~mm}$. The trusses were designed and supplied by a truss manufacturer, using proprietary software which was supplied to the truss manufacturer by one of the South African system suppliers. In the design, it was assumed that the loads would be equally distributed amongst the three trusses even though the light-weight hangers would only be attached to the outer truss. A load of $1 \cdot 1 \mathrm{kN}$ at each hanger was used in sizing the truss members.

Prior to setting up the experiment and the assembly of the girder truss, an analysis was used to determine the theoretical applied loads to result in loads of $2 \mathrm{kN}, 3 \mathrm{kN}$ and $5 \mathrm{kN}$ in the critical web member. The objective was primarily to see which web showed the biggest difference in the forces of the individual plies and secondly to calibrate the flexible load cells for the expected loads.

An analysis of the three-ply girder truss, showed that the short vertical web member had the highest difference in force between the individual plies if the slip between the plies was taken into account. This analysis was used to give an indication of the distribution of forces in a given member of the multiple ply girder truss. The critical members were then cut and a router used to cut a groove into each of the plies, up to the centre, so that a specially prepared thin flexible plate load cell could be glued into place (see Figure 7) The load cells were fixed to the centre so that no moments would be transferred to the plate. It was also decided not to glue strain gauges on the timber, as these could be damaged during the assembly, and the modulus of elasticity of the web members was unknown. Strain gauges would have had to be placed on both sides of the timber to obtain an average reading and the mean modulus of elasticity of the web members would have to be measured prior to assembly of the truss. Gluing long strain gauges onto the timber would have given strains, and at best an indication of the stresses involved.

The trusses were then assembled by nailing and bolting. Two trusses were nailed together with $100 \mathrm{~mm}$ nails, spaced at $250 \mathrm{~mm}$ in the chords and $300 \mathrm{~mm}$ in the webs, that were then clinched. The third truss was added and this was then nailed to the combined truss with $100 \mathrm{~mm}$ long nails, with the same spacing, which then penetrated both laminates of the combined trusses (see Figure 8). This means that the outer loaded truss (truss 1) and the middle truss (truss 2) had two nails at a spacing of $250 \mathrm{~mm}$ and the unloaded outer truss (truss 3 ) only one nail at a spacing of $250 \mathrm{~mm}$ in the chords. Nailing in the top and bottom chords was then later increased, with additional nails spaced at

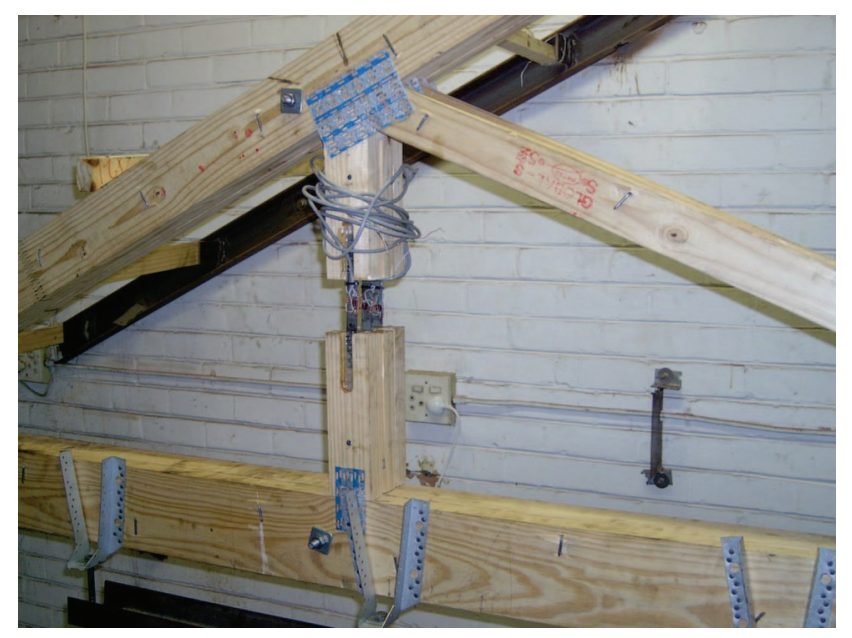

Figure 7. This shows the specially prepared calibrated load cell placed in the web members

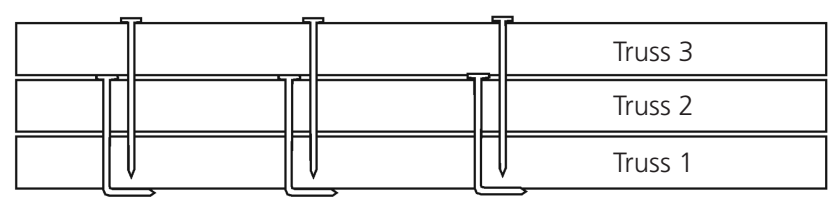

Figure 8. The nailing pattern that is employed when nailing trusses together 
$250 \mathrm{~mm}$, thereby reducing the spacing to $125 \mathrm{~mm}$. The webs were also given additional nails that reduced the spacing to $150 \mathrm{~mm}$.

Instead of seven design loads at $750 \mathrm{~mm}$, the number of loads was increased to eight loads as can be seen in Figure 9. This was done to accommodate the four jacking points that were available in the laboratory. Each jacking point was split to apply two loading points, where the load was then applied to the outer truss by means of truss hangers that were nailed to the outer truss. Nailing of the brackets was done using galvanised ring-shank nails. The force exerted by the jacks was measured using calibrated tension rings with dial gauges.

\subsection{Results of the experimental loading of a three-ply girder truss}

The force in the flexible load cells was measured at each load level

with nails in the chords and webs at $250 \mathrm{~mm}$ and $300 \mathrm{~mm}$, respectively, and then later

with nails in the chords and webs at $125 \mathrm{~mm}$ and $150 \mathrm{~mm}$, respectively.

The web member of the loaded truss was designated as web 1 and the furthest web 3 . The measured results of the forces in the webs are given in Tables 2 and 3 for the larger nail spacing and in Tables 4 and 5 for the case where the nail spacing was halved.

It should be noted that with the lower loads, friction between the timber trusses contributes to the load transfer between the outer loaded truss and the adjacent trusses. As the loads increase, slip between the plies occurs, thereby leading to heavier loads in the outer ply. Girder trusses in the roofs of buildings are subjected to moisture changes: that is, shrinkage and swelling and the friction bond between the trusses will be broken. Larger loads will allow

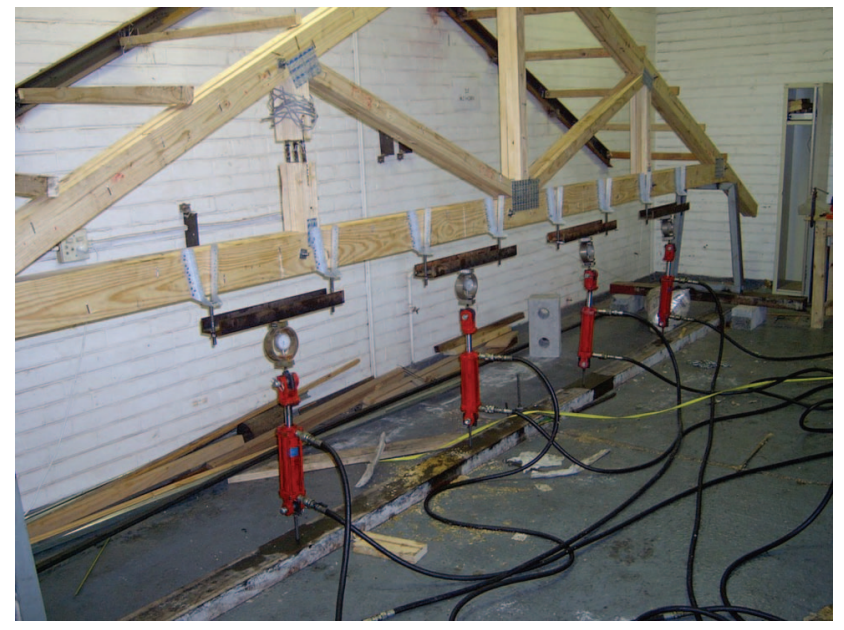

Figure 9. The relative positioning of the loading jacks and the flexible load cells
Web number

Total target load in combined web

\begin{tabular}{lll}
\hline $2 \mathrm{kN}$ & $3 \mathrm{kN}$ & $5 \mathrm{kN}$ \\
\hline
\end{tabular}

Measured in each flexible load cell: kN

\begin{tabular}{llll}
\hline 1 & 1.87 & 2.87 & 4.33 \\
2 & 0.69 & 0.98 & 1.30 \\
3 & 0.64 & 0.76 & 0.86 \\
Total load & 3.20 & 4.61 & 6.49 \\
Average load & 1.07 & 1.54 & 2.16
\end{tabular}

Table 2. Loads measured in individual web member, large nail spacing

\begin{tabular}{|c|c|c|c|}
\hline \multirow[t]{3}{*}{ Web number } & \multicolumn{3}{|c|}{ Total target load in combined web } \\
\hline & $2 \mathrm{kN}$ & $3 \mathrm{kN}$ & $5 \mathrm{kN}$ \\
\hline & \multicolumn{3}{|c|}{ Percentage of total load in web member } \\
\hline 1 & $58 \cdot 44 \%$ & $62 \cdot 26 \%$ & $66 \cdot 72 \%$ \\
\hline 2 & $21 \cdot 56 \%$ & $21 \cdot 26 \%$ & $20.03 \%$ \\
\hline 3 & $20 \cdot 00 \%$ & $16 \cdot 49 \%$ & $13 \cdot 25 \%$ \\
\hline
\end{tabular}

Table 3. Percentage of total load carried by each web member, large nail spacing

\begin{tabular}{lccc}
\hline Web number & \multicolumn{3}{c}{ Total target load in combined web } \\
\cline { 2 - 4 } & $2 \mathrm{kN}$ & $3 \mathrm{kN}$ & $5 \mathrm{kN}$ \\
\cline { 2 - 4 } & \multicolumn{3}{l}{ Measured in each flexible load cell: kN } \\
\hline 1 & 1.94 & 2.89 & 4.41 \\
2 & 0.67 & 0.97 & 1.41 \\
3 & 0.61 & 0.78 & 0.92 \\
Total load & 3.22 & 4.64 & 6.72 \\
Average load & 1.07 & 1.55 & 2.24
\end{tabular}

Table 4. Loads measured in individual web member, halved nail spacing

more slip between the plies giving a more accurate reflection of the loading on multiple-ply girder trusses after shrinkage has occurred.

\subsection{Analytical solution of a three-ply girder truss}

An analysis of a three ply girder was undertaken and compared to the experimental set-up. The modulus of elasticity of all the members was set at $7800 \mathrm{MPa}$ and the flexible load cells were 
Web number

Total target load in combined web

\begin{tabular}{ll}
$2 \mathrm{kN}$ & $3 \mathrm{kN}$ \\
\hline
\end{tabular}

Percentage of total load in web member

\begin{tabular}{llll}
\hline 1 & $60 \cdot 25$ & $62 \cdot 28$ & $65 \cdot 63$ \\
2 & $20 \cdot 81$ & 20.91 & 20.98 \\
3 & 18.94 & 16.81 & 13.69
\end{tabular}

Table 5. Percentage of total load carried by each web member, halved nail spacing

modelled as steel members with the same dimensions as the load cells and fixed to the timber elements. No allowance was made for overlap between the steel and the timber where the load cells were glued to the timber. This was not seen to influence the results significantly, as $18 \mathrm{~mm}$ of the timber member was removed and replaced with equivalent of $26 \mathrm{~mm}$ of timber. The local stiffness would have increased by about $6 \%$, and this would not have made a significant difference to the overall stiffness of the web member.

Table 6 gives the size and properties of the members used to assemble the three-ply girder truss. A three-dimensional linear elastic centreline analysis was undertaken and the assumption was made that the joints were fixed about both axes. This was done so that truss suppliers, who use linear elastic analyses, could use this method to obtain a far more realistic value for the loading in the trusses than is presently assumed: that is, load shared equally among the trusses.

An analysis was undertaken with the trusses spaced next to each other with a distance of $36 \mathrm{~mm}$ between the centrelines of the planes of the trusses (see Figure 10). The nails were spaced at $250 \mathrm{~mm}$ in the chords and at $300 \mathrm{~mm}$ in the webs. Hanger loading of $3 \mathrm{kN} /$ hanger was applied so that the combined force in the webs was about the same as the heaviest load of $5 \mathrm{kN}$ in the experiment. A linear elastic analysis was used and, initially, web to chord connections were assumed to be fixed. The eccentricity of the load was taken into account by applying a torsional moment

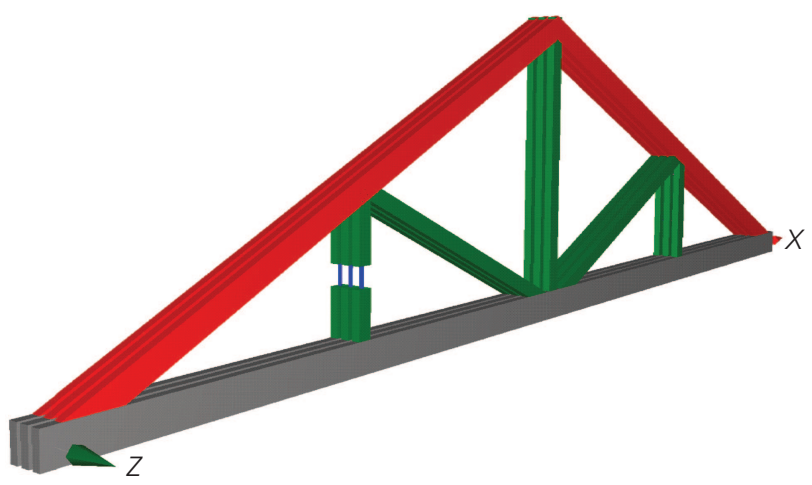

Figure 10. Analysis model for trusses placed next to each other. Trusses joined by means of flexural elements to model the nails

of $60 \%$ of the possible torsion at the hanger positions. This was done as a certain amount of torsional, as well as lateral restraint, was provided by the loading mechanism in the experiment.

The results of the analysis of the forces found in the web that was monitored during the experimental loading of the three-ply girder truss are given in Tables 7 and 8 for the trusses with chord nailing at $250 \mathrm{~mm}$ and web nailing at $300 \mathrm{~mm}$. Table 9 gives the results of the analysis for the change in nailing stiffness, once additional nails had been placed between the first series of nails.

In addition to obtaining the relative forces in the web, it was also possible to find the relative size of the bending moments in each bottom chord as a result of the slip between the plies. Figure 11 shows the relative sizes and how the bending moments vary from one truss to the other.

For interest $6 \mathrm{~m}$ span, two-, three- and four-ply girder trusses with a pitch of $26^{\circ}$ were analysed using the same method as the previously described, however, this time without the flexible load cells in the one web. This was done to see whether it would be possible to achieve the same multiplication factors as obtained by Enjily and Whale. The nailing pattern as specified in SANS 10243: 2013 (SANS, 2013), was used. As with the work done by Enjily and Whale (1994), from the full torsional moment to $60 \%$ of the full moment was applied. It was assumed that light

\begin{tabular}{lccccc}
\hline Member & $b: \mathrm{mm}$ & $h: \mathrm{mm}$ & Area: $\mathrm{m}^{2}$ & $\begin{array}{c}\text { Second moment of } \\
\text { area, IX: } \mathrm{m}^{4}\end{array}$ & $\begin{array}{c}\text { Modulus of } \\
\text { elasticity: GPa }\end{array}$ \\
\hline Bottom chord & 36 & 111 & $3.996 \times 10^{-3}$ & $4.103 \times 10^{-6}$ & 7.8 \\
Top chord & 36 & 111 & $3.996 \times 10^{-3}$ & $4.103 \times 10^{-6}$ & 7.8 \\
Webs & 36 & 73 & $2.628 \times 10^{-3}$ & $1.167 \times 10^{-6}$ & 7.8 \\
Nails & 4 mm diameter & $100 \mathrm{~mm}$ long & $7.854 \times 10^{-5}$ & $4.909 \times 10^{-10}$ & 206 \\
Plate load cells & 20 & 2 & $4.0 \times 10^{-5}$ & $1.333 \times 10^{-9}$ & 206
\end{tabular}

Table 6. Sizes and assumed mechanical properties of members in the test truss and analysis thereof 


\begin{tabular}{lccc} 
Web number & Calculated & $\begin{array}{c}\text { Percentage of } \\
\text { total load in } \\
\text { each web }\end{array}$ & $\begin{array}{c}\text { Measured } \\
\text { percentage of } \\
\text { total load in each } \\
\text { web (De Koning) }\end{array}$ \\
\hline 1 & 4.61 & 71.80 & 66.67 \\
2 & 1.38 & 21.50 & 20.00 \\
3 & 0.43 & 6.70 & 13.33 \\
Total load & 6.42 & $100 \%$ & $100 \%$
\end{tabular}

Table 7. Load in each individual web member, compared with the test values. Nails placed at $250 \mathrm{~mm}$ in the chords and $300 \mathrm{~mm}$ in the webs. Torsion applied at the position of the jacking force

\begin{tabular}{lccc} 
Web number & Calculated & $\begin{array}{c}\text { Percentage of } \\
\text { total load in } \\
\text { each web }\end{array}$ & $\begin{array}{c}\text { Measured } \\
\text { percentage of } \\
\text { total load in each } \\
\text { web (De Koning) }\end{array}$ \\
\hline 1 & 4.17 & $64.87 \%$ & $66.67 \%$ \\
2 & 1.60 & $24.87 \%$ & $20.00 \%$ \\
3 & 0.66 & $10.27 \%$ & $13.33 \%$ \\
Total load & 6.43 & $100 \%$ & $100 \%$
\end{tabular}

Table 8. Load in each individual web member, compared with the test values. Nails placed at $250 \mathrm{~mm}$ in the chords and $300 \mathrm{~mm}$ in the webs. No torsion applied at the position of the jacking force; however, the outer was truss loaded in the plane on the centreline of the truss

\begin{tabular}{lcrc} 
Web number & Calculated & $\begin{array}{c}\text { Percentage of } \\
\text { total load in } \\
\text { each web }\end{array}$ & $\begin{array}{c}\text { Measured } \\
\text { percentage of } \\
\text { total load in each } \\
\text { web (De Koning) }\end{array}$ \\
\hline 1 & $4 \cdot 12$ & $64.17 \%$ & $65 \cdot 67 \%$ \\
2 & 1.7 & $26.47 \%$ & $21.00 \%$ \\
3 & 0.6 & $9.33 \%$ & $13.67 \%$ \\
Total load & 6.42 & $100 \%$ & $100 \%$
\end{tabular}

Table 9. Load in each individual web member, compared with the test values. The analysis was performed with the equivalent of three nails between outer loaded truss and inner truss and two nails between inner and outer unloaded truss, i.e. nail spacing halved. No torsion was applied at the position of the jacking force; however, the outer truss was loaded in the plane of the truss

hangers, nailed to the outside of the loaded truss, would be used and for simplicity, a load of $2 \mathrm{kN}$ would be applied. The force in the critical web member was determined and the outer loaded truss member force was then found.

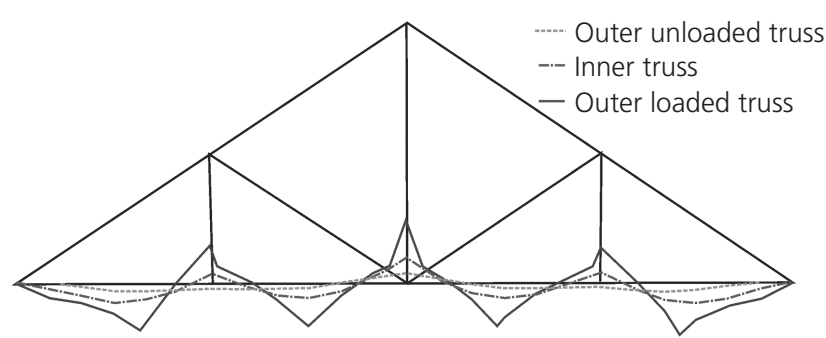

Figure 11. Relative size of the bending moments in the bottom chord as a result of the point loads at the hanger positions

\section{Conclusion}

The above analytical and experimental investigation has shown that by ignoring the eccentric loading and relative slip between the trusses, the member and plate forces may be underestimated by a factor in excess of two for a three ply girder truss. The analytical results seem to indicate that the relative slip between the trusses may have a bigger magnification factor on the forces in the plates and members than the torsional moment on the bottom chord as a result of the eccentric loading, as shown in Table 10, than those found by Enjily and Whale. In the opinion of the authors the magnification factors, based on work by Enjily and Whale (1994), in BS 5268-3:2006 (BSI, 2007) are possibly lower than they should be.

Although there is a significant difference between the values proposed by Enjily and Whale (1994) and the theoretical analysis, it is evident that making the assumption about the load being shared equally among the three plies, is anything but safe. Table 9 shows that there is a remarkable similarity between the analytical solution and the experimental findings of De Koning (2005), especially, in terms of the proportion of the load carried by the outer loaded truss. The authors are under no illusion that a single experiment is statistically significant; however, it shows a trend and makes it possible to calibrate the analytical model.

The model used by Enjily and Whale (1994) did not show nailing patterns or number of nails between the plies and this lead the authors to believe that the relative slip between the plies was not taken into account. More testing of the concept of modelling nails as bending members in double flexure is required before a recommendation can be made about relative size of the bending moments in the bottom chords and the loads in the web members.

The stiffness of the nail plated joints could play a part in the force that is generated in the web member. However, as the plate sizes vary from girder truss to girder truss, a vast number of analytical solutions would be necessary to evaluate the significance of the plate stiffness. Further to this, the type of hanger, whether it is connected to the bottom chord only or whether it is connected to the web will also make a difference to the distribution of the forces throughout the multiple-ply girder trusses. It is noteworthy that in the test programme by Enjily and 


\begin{tabular}{lccccc}
\hline \multirow{2}{*}{ Number of plies } & \multicolumn{5}{c}{ Degree of restraint: $T_{\mathrm{r}}$} \\
\cline { 2 - 6 } & $T_{\mathrm{r}}=0$ & $T_{\mathrm{r}}=0 \cdot 1$ & $T_{\mathrm{r}}=0 \cdot 2$ & $T_{\mathrm{r}}=0 \cdot 3$ & $T_{\mathrm{r}}=0 \cdot 4$ \\
\hline 1 & 1.0 & $1 \cdot 0$ & $1 \cdot 0$ & $1 \cdot 0$ & $1 \cdot 0$ \\
2 & $1 \cdot 61,(1 \cdot 33)$ & $1 \cdot 59,(1 \cdot 13)$ & $1 \cdot 57,(1 \cdot 13)$ & $1 \cdot 55,(1 \cdot 13)$ & $1 \cdot 53,(1 \cdot 13)$ \\
3 & $2 \cdot 29,(2 \cdot 00)$ & $2 \cdot 26,(1 \cdot 70)$ & $2 \cdot 24,(1 \cdot 40)$ & $2 \cdot 19,(1 \cdot 40)$ & $2 \cdot 16,(1 \cdot 40)$ \\
4 & $3 \cdot 00,(3 \cdot 00)$ & $2 \cdot 96,(2 \cdot 60)$ & $2 \cdot 90,(2 \cdot 20)$ & $2 \cdot 81,(1 \cdot 80)$ & $2 \cdot 80,(1 \cdot 80)$ \\
\hline
\end{tabular}

Values in brackets are those proposed by Enjily and Whale (1994)

Table 10. Proposed force magnification factors for eccentrically loaded components

Whale (1994) it appears as if the hangers that they used folded over the top of the multiple plies and were nailed to the other trusses, whereas in the test done by De Koning (2005) the hanger was nailed to the outside of one truss.

\section{REFERENCES}

Bosch HH (2005) The Flexural Stiffness of Composite Timber members when Using Flexible Shear connectors: A Comparative Study. Preliminary Report towards $\mathrm{PhD}$ Dissertation, Department of Civil Engineering, University of Pretoria, Pretoria, South Africa.

BSI (1998) BS 5268-3:1998: Structural use of timber. Code of practice for trussed rafter roofs. BSI, London, UK.

BSI (2007) BS 5268-3:2006, Part 3: Code of practice for trussed rafter roofs, including corrigendum no. 2. BSI, London, UK.

BSI (2008) Design of timber structures. Part 1-1: General - rules and rules for buildings. BS EN 1995-1-1:2004 + A1:2008. BSI, London, UK.

Burdzik WMG and NKwera PD (2003) The relationship between torsional rigidity and bending strength characteristics of S A pine. South African Forestry Journal 198(July): 17-21.

Burdzik WMG (2005) The effect of the relative slip between plies of multi-ply girder trusses subjected to single face loading. Journal of the South African Institution of Civil Engineers 47(4): $12-17$.

Coates RC, Coutie MG and Kong FK (1988) Structural Analysis, 2nd edn. Thomas Nelson and Sons, London, UK.

Dekker NW and Burdzik WMG (2000) A rational approach to the design of bracing to resist stability forces and a review of the CSA S16-1-99 proposal. Journal of the South African Institution of Civil Engineers 42(1): 2-6.

De Koning L (2005) Determination of load-sharing between plies of multi-ply girder truss. Project Report in Partial Fulfilment for the Degree of Bachelor of Engineering (Civil Engineering), University of Pretoria, Pretoria, South Africa.

Enjily $V$ and Whale $L$ (1994) The performance of trussed girders under eccentric loading. Proceedings of the Pacific Timber Engineering Conference, Gold Coast, Australia.

Prokon Software Consultants Ltd (2011) PROKON Suite of Structural Analysis Programs. Prokon, Pretoria, South Africa.
SANS (South African National Standards) (1992) SANS 10243:1992: Code of practice for the manufacture and erection of timber trusses. South African Bureau of Standards, Pretoria, South Africa.

SANS (2001) SANS 10163-2:2001: The structural use of timber. Part 2: Allowable stress design. South African Bureau of Standards, Pretoria, South Africa.

SANS (2003a) SANS 10163-1:2003: The structural use of timber. Part 1: Limit-states design. South African Bureau of Standards, Pretoria, South Africa.

SANS (2003b) SANS 10243:2003: Code of practice for the manufacture and erection of timber trusses. South African Bureau of Standards, Pretoria, South Africa.

SANS (2013) SANS10243, 2013: The manufacture and erection of timber trusses. South African Bureau of Standards, Pretoria, South Africa.

Truss Plate Institute (2002) Proposed American national standard, National Design Standard for Metal Plate Connected Wood Truss Construction, BSR/TPI 1-2002, Draft 5. American National Standards Institute, Washington, DC, USA. 